\title{
Effects of Calcination on the Crystallography and Nonbiogenic Aragonite Formation of Ark Clam Shell under Ambient Condition
}

\author{
Chee Wah Loy, ${ }^{1,2}$ Khamirul Amin Matori, ${ }^{1,3}$ Way Foong Lim, ${ }^{3}$ \\ Siegbert Schmid, ${ }^{2}$ Norhazlin Zainuddin, ${ }^{4}$ Zaidan Abdul Wahab, ${ }^{1}$ \\ Zarifah Nadakkavil Alassan, ${ }^{1}$ and Mohd Hafiz Mohd Zaid ${ }^{1}$ \\ ${ }^{1}$ Department of Physics, Faculty of Science, Universiti Putra Malaysia (UPM), 43400 Serdang, Selangor, Malaysia \\ ${ }^{2}$ School of Chemistry, The University of Sydney, F11, Eastern Avenue, Sydney, NSW 2006, Australia \\ ${ }^{3}$ Materials Synthesis and Characterization Laboratory, Institute of Advanced Technology, Universiti Putra Malaysia (UPM), \\ 43400 Serdang, Selangor, Malaysia \\ ${ }^{4}$ Department of Chemistry, Faculty of Science, Universiti Putra Malaysia (UPM), 43400 Serdang, Selangor, Malaysia
}

Correspondence should be addressed to Khamirul Amin Matori; khamirul@upm.edu.my

Received 18 November 2015; Accepted 11 January 2016

Academic Editor: Michele Iafisco

Copyright (C) 2016 Chee Wah Loy et al. This is an open access article distributed under the Creative Commons Attribution License, which permits unrestricted use, distribution, and reproduction in any medium, provided the original work is properly cited.

\begin{abstract}
This paper presents a study of crystallographic evolution of disposed ark clam shell (ACS) after calcination at $400-1400^{\circ} \mathrm{C}$ which was kept at room temperature under ambient condition in Malaysia during nine months. A better understanding of hydration and recarbonation of ACS powder $(\leq 63 \mu \mathrm{m})$ after calcination was discovered by PXRD and FTIR. The research focuses on the crystallographic transformation, biogenic calcite decomposition, and unusual atmospheric aragonite formation in ACS after calcination and atmospheric air exposure. Ex situ PXRD showed calcite present in ACS at $\leq 900^{\circ} \mathrm{C}$. ACS transformed to pyrogenic $\mathrm{fcc} \mathrm{CaO}$ at $\geq 800^{\circ} \mathrm{C}$ after three months. Long term atmospheric air exposure of decarbonized ACS caused nucleation of nonbiogenic aragonite, vaterite, calcite, and portlandite. However, in situ PXRD analysis of ACS at instantaneous temperature without cooling process does not indicate the presence of aragonite, vaterite, and portlandite crystals. FTIR spectra revealed $\mathrm{CaO}-\mathrm{CO}_{2}$ bond in ACS dissociated with temperature $\left(600-900^{\circ} \mathrm{C}\right)$ to form $\mathrm{CaO}$ and $\mathrm{CO}_{2}$. Ca-OH bond was also traced in FTIR spectra of $\geq 700^{\circ} \mathrm{C}$. It resulted by hydroadsorption of $\mathrm{CaO}$ with $\mathrm{H}_{2} \mathrm{O}$ in atmospheric air.
\end{abstract}

\section{Introduction}

There are many aquatic organisms such as bivalve seashells which consist of exoskeleton which is made by biomineralization of calcium carbonate $\left(\mathrm{CaCO}_{3}\right)$. Many species of bivalve seashells are our seafood. Their shells may consist of naturally formed biogenic $\mathrm{CaCO}_{3}$ which exist in several crystallographic polymorphs such as calcite (R-trigonal), aragonite (Porthorhombic), and vaterite (P-hexagonal) [1,2]. The difference in the crystalline phases precipitated during biomineralization depends on the nucleation barrier, $\mathrm{pH}$, temperature, and concentrations of some inorganic mineral ions in sea water [3, 4]. In general, most clam shells (e.g., Anadara granosa) and oyster shells (e.g., Crassostrea gigas) consist of biogenic calcite [5-7], whereas mussels [7], Acanthocardia tuberculata [8], Unio terminalis [9], Nautilus macromphalus [9], and abalone shells [10] consist of biogenic aragonite.

In nature, aragonite formed by geogenic process under high pressure at low temperature or biogenic process [11]. Besides, $\mathrm{CaCO}_{3}$ also exists naturally in three pseudopolymorphs of hydrated $\mathrm{CaCO}_{3}$. They are amorphous $\mathrm{CaCO}_{3} \cdot x \mathrm{H}_{2} \mathrm{O}(x \approx 1)$, P-hexagonal $\mathrm{CaCO}_{3} \cdot \mathrm{H}_{2} \mathrm{O}$ (monohydrocalcite), and $\mathrm{C}$-monoclinic $\mathrm{CaCO}_{3} \cdot 6 \mathrm{H}_{2} \mathrm{O}$ (ikaite) crystals [12-15]. The species of ark clam is being chosen for our research because it solely consists of biogenic calcite and is the most consumed seafood bivalve in Malaysia and most countries. It is categorized under the kingdom of Animalia, phylum of Mollusca, class of Bivalvia, subclass of 
Pteriomorphia, order of Arcoida, family of Arcidae, genus of Anadara, and species of granosa [16]. The shells of ark clam (ACS) contribute large amount of solid waste. ACS is primarily composed of $\mathrm{CaCO}_{3}$ which is mostly in the form of calcite. When sufficient heat is applied to calcite, it will decompose to form calcium oxide $(\mathrm{CaO})$ and release carbon dioxide $\left(\mathrm{CO}_{2}\right)$ gas.

In this study, we reported crystallographic evolution and unusual nonbiogenic aragonite formation of disposed ACS powder after calcination at $400-1400^{\circ} \mathrm{C}$ for 3 hours followed by slow cooling rate $\left(-10^{\circ} \mathrm{C} \mathrm{min}^{-1}\right)$ under moist atmospheric air and pressure in Malaysia which has not been reported by other researchers. Disposed ACS was used as a source of high crystallinity biogenic calcite. Utilization of ACS and other seafood shells can reduce lands for mining limestone and reduce solid waste associated with seafood industries. Partial pressures of carbon dioxide in atmospheric air affect the recarbonation of decarbonized ACS, whereas partial pressure of water vapour in atmospheric air affects hydroadsorption of hygroscopic $\mathrm{CaO}$ during cooling process. The ambient condition also caused recarbonation of pyrogenic fcc $\mathrm{CaO}$ to form atmospheric aragonite and atmospheric calcite by $\mathrm{CO}_{2}-$ chemoadsorption. The formation of aragonite from $\mathrm{CaO}$ under ambient condition is unusual because it is thermodynamically less stable compared to calcite. It was first discovered by Loy (2012) and further discussed in this paper. PXRD and FTIR analyses were carried out to describe the decomposition of calcite, formation of aragonite, and hydroadsorption of $\mathrm{CaO}$ in terms of crystallography and chemical bonds change of ACS [17].

\section{Materials and Methods}

The raw material of this study was fresh disposed ACS by seafood industries in West Peninsular Malaysia. The ACS originates from Straits of Malacca. ACS was immersed into bleaching detergent $(0.5-2 \%$ of sodium hypochlorite, $\mathrm{NaClO}$ ) for 30 minutes and then rinsed with water. $\mathrm{NaClO}$ was practically used by other researchers before to remove organic compounds on calcium-based materials such as aragonite, hydroxyapatite, and bone [18-20]. Clean ACS was ground into powder $(\leq 63 \mu \mathrm{m})$ and tested by PXRD under wide range of angles $\left(10-130^{\circ}\right)$ to identify the purity of crystals.

Clean ACS was also heated at $400^{\circ} \mathrm{C}$ for 3 hours to be brittle, easy to grind, and free of organic compounds. The ACS was ground into powder $(\leq 63 \mu \mathrm{m})$ for in situ PXRD analysis under ambient condition. In situ PXRD analysis was performed by PANalytical X'Pert Pro PW3050/60 diffractometer with $\mathrm{CuK}_{\alpha}$ radiation and stage furnace to characterize ACS powder while being heated at $600-1000^{\circ} \mathrm{C}$ under ambient condition. The decomposition temperature and phase transformation of calcite under ambient condition were determined.

In order to study the effect of atmospheric air in Malaysia on ACS after calcination, ACS powder was calcined at various temperatures $\left(400-1400^{\circ} \mathrm{C}\right)$ for 3 hours in an electric furnace under ambient condition. Each calcined ACS powder was heated with a rate of $+10^{\circ} \mathrm{C} \mathrm{min}^{-1}$, remained at calcination temperature for 3 hours, and then cooled with a rate of $-10^{\circ} \mathrm{C} \mathrm{min}^{-1}$ to room temperature. The products of calcination were reground into powder $(\leq 63 \mu \mathrm{m})$ and kept for three and nine months for further analyses. Ex situ PXRD test was also carried out by PANalytical X'Pert Pro PW3050/60 diffractometer with $\mathrm{CuK}_{\alpha}$ radiation at room temperature to characterize calcined ACS powder. The scanning angles $(2 \theta)$ of ex situ PXRD were $10-70^{\circ}$. The decomposition temperature and phase transformation of calcite under ambient condition were determined. The result was compared to the in situ PXRD patterns of ACS after calcination under ambient condition.

FTIR spectroscopy was performed by PerkinElmer Spectrum 100 Series with universal attenuated total reflectance (UATR) technique to identify the chemical bonds existing in the calcined ACS powder after three months. The wave number range of IR spectra was $4000-280 \mathrm{~cm}^{-1}$. The infrared (IR) absorption of calcite is contributed by three intramolecular $\left(v_{3}=1484, v_{4}=706\right.$, and $\left.v_{2}=885 \mathrm{~cm}^{-1}\right)$, three translator lattice $\left(357,330\right.$, and $\left.182 \mathrm{~cm}^{-1}\right)$, and two rotator lattice vibrations $\left(106 \mathrm{~cm}^{-1}\right)[21,22]$. Farmer $(1974)$ stated that the three intramolecular modes are strongly polarized bands in the mid-IR, whereas the other five are in the far-IR [23]. Reig et al. (2002) used constant ratio method in the FTIR quantitative analysis of calcite. They found the IR absorption bands of calcite at 1420,875 , and $712 \mathrm{~cm}^{-1}$ [2]. Presence of aragonite can be identified obviously from IR absorption band of symmetric stretch vibration $v_{1}$ which is IR-active. According to Bhagavantam and Venkatarayudu (1939), the IR bands of aragonite are positioned at $v_{3}=1504,1492 ; v_{1}=1080$; $v_{4}=711,706$; and $v_{2}=866 \mathrm{~cm}^{-1}$, whereas those of calcite are positioned at $v_{3}=1429-1492 ; v_{4}=706$; and $v_{2}=879 \mathrm{~cm}^{-1}$ [24]. Farmer (1974) showed the FTIR spectrum of $\mathrm{CaO}$ with impurities of $\mathrm{Ca}(\mathrm{OH})_{2}$ and $\mathrm{CaCO}_{3}$ [23]. The spectrum consists of a broad band at 700-200 $\mathrm{cm}^{-1}$ (overlapping of $\mathrm{CaO}$ and $\mathrm{CaCO}_{3}$ absorption) and a sharp band at $\sim 3600 \mathrm{~cm}^{-1}$ $\left(\mathrm{Ca}(\mathrm{OH})_{2}\right.$ absorption).

Chen and Xiang (2009) studied the three polymorphs of synthetic $\mathrm{Ca}(\mathrm{CO})_{3}$ through displacement reaction of salt solutions $\left(\mathrm{CaCl}_{2}\right.$ and $\left.\mathrm{NH}_{4} \mathrm{HCO}_{3}\right)$ at $30-80^{\circ} \mathrm{C}$ [1]. They provided PXRD pattern and FTIR spectra to show crystals transformation of vaterite and calcite to aragonite. They stated that $v_{2}$ and $v_{4}$ vibrations of $\mathrm{CO}_{3}{ }^{2-}$ bonds in vaterite are 877 and $744 \mathrm{~cm}^{-1}$, respectively, whereas the vibrations of calcite bonds are 848 and $714 \mathrm{~cm}^{-1}$, respectively. The IR absorption at $v_{2}=$ $854, v_{4}=712$, and $v_{4}=700 \mathrm{~cm}^{-1}$ corresponds to the vibrations of $\mathrm{CO}_{3}{ }^{2-}$ bonds in aragonite.

Ruiz et al. (2009) characterized $\mathrm{Ca}(\mathrm{CO})_{3}, \mathrm{CaO}$, and $\mathrm{Ca}(\mathrm{OH})_{2}$ from lime for constructive application through PXRD and FTIR [25]. The IR absorption of $\mathrm{CaCO}_{3}$ is positioned at 2875 ( $\mathrm{C}=\mathrm{O}$ bond), 1795 ( $\mathrm{C}=\mathrm{O}$ bond), 1444 (C-O bond), 877 ( $\mathrm{C}-\mathrm{O}$ bond), and $474 \mathrm{~cm}^{-1}$ ( $\left.\mathrm{Ca}-\mathrm{O}\right)$. Two strong bands at 1444 and $877 \mathrm{~cm}^{-1}$ as well as a weak band at $713 \mathrm{~cm}^{-1}$ correspond to elongation modes of $\mathrm{Ca}-\mathrm{O}$ bond of calcite. Mid-IR ranges of both $\mathrm{CaO}$ and $\mathrm{Ca}(\mathrm{OH})_{2}$ spectra are almost similar. Presence of $\mathrm{CaO}$ was indicated by IR absorption bands at $3643,1417,866$, and $511 \mathrm{~cm}^{-1}$, whereas presence of $\mathrm{Ca}(\mathrm{OH})_{2}$ was indicated by IR absorption bands at $3643,2513,1427,1126,875$, and $457 \mathrm{~cm}^{-1}$. However, less 


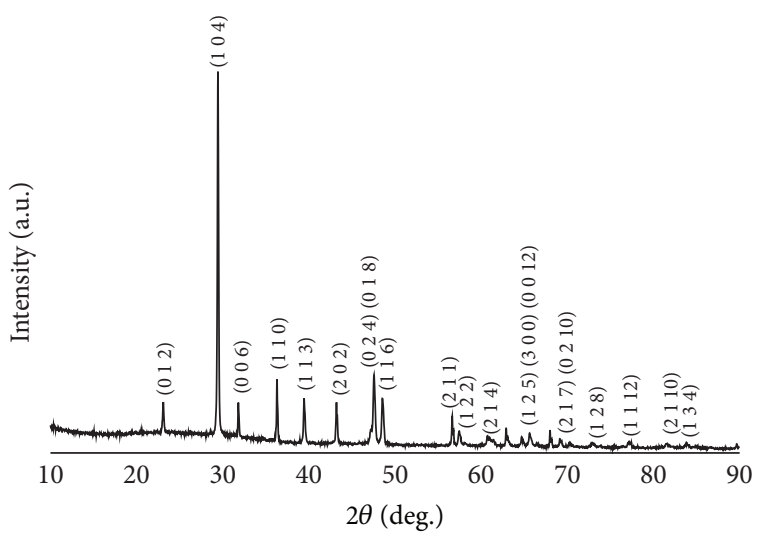

FIGURE 1: PXRD pattern of fresh ACS before calcination, where $(h, k, l)$ are Miller indices of peaks attributed to $\mathrm{R}$-trigonal $\mathrm{CaCO}_{3}$ crystal.

hydrated $\mathrm{CaO}$ has a weaker band at $3643 \mathrm{~cm}^{-1}$ compared to $\mathrm{Ca}(\mathrm{OH})_{2}$.

\section{Result and Discussion}

PXRD test on ACS before calcination revealed that ACS consists of high crystallinity of R-trigonal $\mathrm{CaCO}_{3}$ (biogenic calcite). No impure crystal was traced in the PXRD result in $10^{\circ}<2 \theta<130^{\circ}$. Figure 1 shows the PXRD result in diffraction angle range of $10-90^{\circ}$ which consists of most informative peaks which corresponded to calcite. These peaks are located at $2 \theta$ (Miller indices) $=23.12^{\circ}\left(\begin{array}{lll}0 & 1 & 2\end{array}\right), 29.46^{\circ}\left(\begin{array}{lll}1 & 0 & 4\end{array}\right), 31.84^{\circ}(0$ $06), 36.33^{\circ}$ (1 110$), 39.45^{\circ}$ (1 113$), 43.19^{\circ}(202), 47.56^{\circ}(018)(0$ $24), 48.53^{\circ}(116), 56.63^{\circ}(211), 57.43^{\circ}$ (1 2 2), 60.71 (2 14 ), $62.89^{\circ}(125), 64.70^{\circ}(300), 65.62^{\circ}(0012), 69.21^{\circ}(217), 70.32^{\circ}$ (0 210$), 72.96^{\circ}(128), 77.22^{\circ}$ (1 112$), 81.58^{\circ}$ (2 10$)$, and $83.88^{\circ}$ (1 34 ). They were well matched with the ICSD 073446.

In situ PXRD scanning was also carried out on ACS heated from room temperature to $1000^{\circ} \mathrm{C}$ in a PXRD instrument installed with a stage furnace accessory. Crystallographic evolution of ACS at instantaneous temperature under atmospheric air and pressure was investigated. The in situ PXRD result of ACS at $600-1000^{\circ} \mathrm{C}$ is shown in Figure 2. It revealed that biogenic calcite in ACS powder slightly grows at $600-650^{\circ} \mathrm{C} . \mathrm{CaCO}_{3}$ began to decompose to $\mathrm{fcc} \mathrm{CaO}$ at $650^{\circ} \mathrm{C}$. Three major peaks of fcc $\mathrm{CaO}$ were found in the PXRD pattern at $31.79^{\circ}, 36.93^{\circ}$, and $53.28^{\circ}$. Calcite in ACS does not transform into other polymorphs of $\mathrm{CaCO}_{3}$ before decomposition. Calcite fully decomposed to form fcc $\mathrm{CaO}$ at $800^{\circ} \mathrm{C}$. The fcc $\mathrm{CaO}$ only slightly grows towards $1000^{\circ} \mathrm{C}$.

Figure 3 shows the ex situ PXRD patterns of ACS powder after calcination at $600-1000^{\circ} \mathrm{C}$ for 3 hours and cooling down to room temperature with a rate of $-10^{\circ} \mathrm{C} \mathrm{min} \mathrm{m}^{-1}$ under ambient condition. The PXRD pattern of ACS after calcination at $600^{\circ} \mathrm{C}$ showed a set of peaks attributed to calcite. Few major peaks of fcc $\mathrm{CaO}$ observed in the PXRD pattern of $700^{\circ} \mathrm{C}$ revealed that the biogenic calcite began to be decarbonized to form pyrogenic fcc $\mathrm{CaO}$ nucleate $[5,26,27]$. Calcite peaks intensity was diminished in the PXRD patterns

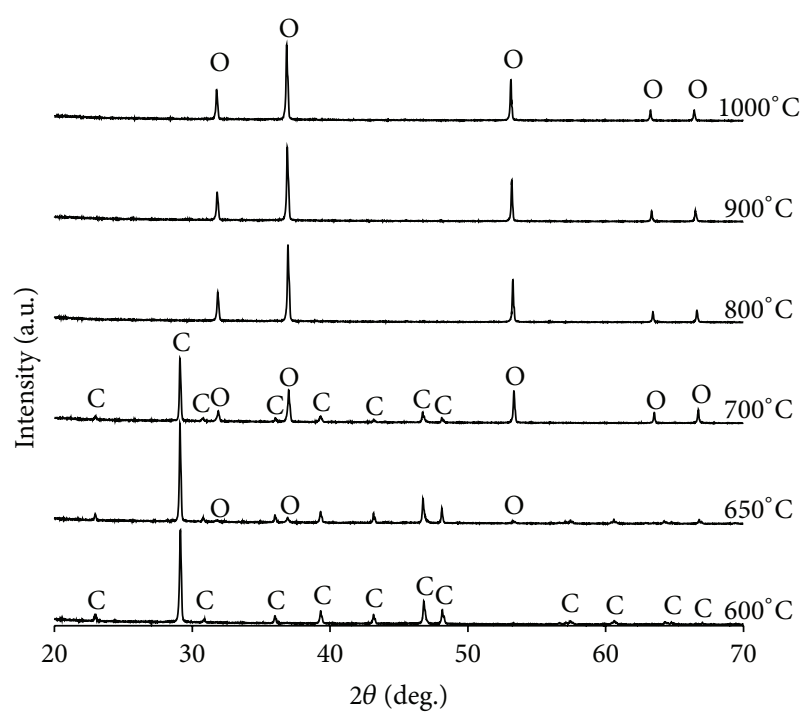

FIGURE 2: In situ PXRD patterns of ACS when calcined at 600$1000^{\circ} \mathrm{C}$ under ambient condition $(\mathrm{C}=$ calcite; and $\mathrm{O}=\mathrm{fcc} \mathrm{CaO})$.

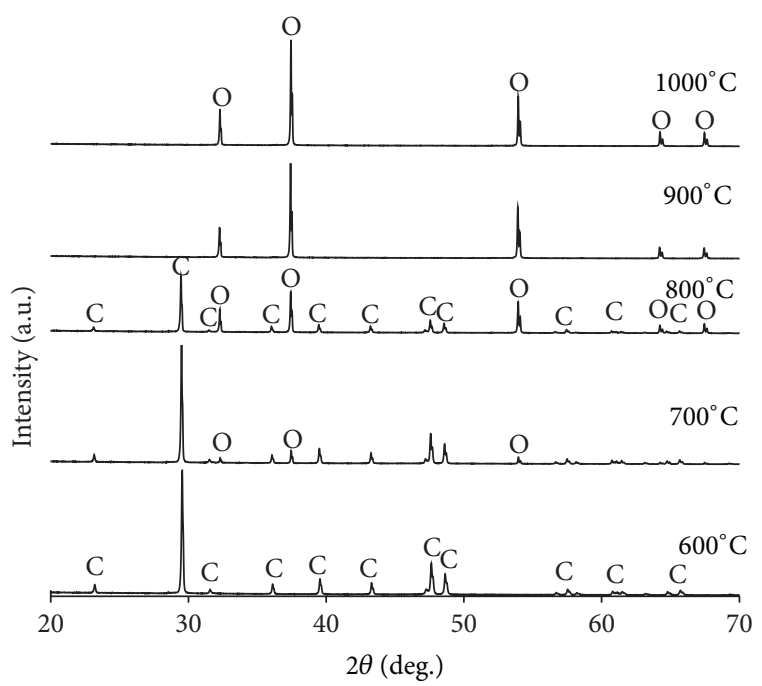

FIGURE 3: PXRD patterns of ACS after calcination at $600-1000^{\circ} \mathrm{C}$ for 3 hours and cooling down with $-10^{\circ} \mathrm{C} \mathrm{m^{-1 }}$ under ambient condition $(\mathrm{C}=$ calcite; $\mathrm{O}=\mathrm{fcc} \mathrm{CaO})$.

of $700-800^{\circ} \mathrm{C}$ and fully disappeared in the PXRD patterns of $900-1000^{\circ} \mathrm{C}$. Full set of fcc $\mathrm{CaO}$ peaks was observed in the PXRD patterns of $800-1000^{\circ} \mathrm{C}$. The increment of the fcc $\mathrm{CaO}$ peaks intensity in the patterns of $700-1000^{\circ} \mathrm{C}$ revealed that the crystal was growing in the temperature range. The pyrogenic fcc $\mathrm{CaO}$ peaks in the pattern of $1000^{\circ} \mathrm{C}$ were positioned at $2 \theta$ (Miller indices) $=32.29^{\circ}$ (1 111$), 37.45^{\circ}(20$ 0 ), $53.95^{\circ}$ (2 20$), 64.24^{\circ}$ (3 1 1), and $67.47^{\circ}$ (2 22 ) sharply.

Figure 4 shows the ex situ PXRD patterns of ACS powder after calcination at $400-1400^{\circ} \mathrm{C}$ which were kept at room temperature under ambient condition for three months. The main objective of this analysis is to observe time-dependent crystallography evolution of ACS due to recarbonation and hydroadsorption of pyrogenic fcc $\mathrm{CaO}$. The identities of 
TABLE 1: Several crystal structures of calcium compounds present in ACS after calcination and kept under ambient condition for three months.

\begin{tabular}{|c|c|c|c|c|c|}
\hline Mineral name & Calcite & Aragonite & Vaterite & Portlandite & Lime \\
\hline Molecular formula & $\mathrm{CaCO}_{3}$ & $\mathrm{CaCO}_{3}$ & $\mathrm{CaCO}_{3}$ & $\mathrm{Ca}(\mathrm{OH})_{2}$ & $\mathrm{CaO}$ \\
\hline ICSD code & 073446 & 032100 & 18127 & 202231 & 75785 \\
\hline Crystal system & Trigonal & Orthorhombic & Hexagonal & Trigonal & Cubic \\
\hline Bravais lattice & Rhombohedral & Primitive & Primitive & Primitive & Face-centered \\
\hline Space group & $\mathrm{D}_{3 \mathrm{~d}}^{6}(\mathrm{R} \overline{3} \mathrm{c})$ & $\mathrm{D}_{2 \mathrm{~h}}^{16}(\mathrm{Pmcn})$ & $\mathrm{D}_{6 \mathrm{~h}}^{4}\left(\mathrm{P}_{3} / \mathrm{mmc}\right)$ & $\mathrm{D}_{3 \mathrm{~d}}^{3}(\mathrm{P} \overline{3} \mathrm{~m} 1)$ & $\mathrm{O}_{\mathrm{h}}^{4}(\mathrm{Fm} \overline{3} \mathrm{~m})$ \\
\hline $\mathrm{a}(\mathrm{nm})$ & 0.4991 & 0.49610 & 7.135 & 0.36041 & 0.48106 \\
\hline $\mathrm{b}(\mathrm{nm})$ & 0.4991 & 0.79670 & 7.135 & 0.36041 & 0.48106 \\
\hline $\mathrm{c}(\mathrm{nm})$ & 1.7062 & 0.57410 & 16.98 & 0.49620 & 0.48106 \\
\hline
\end{tabular}

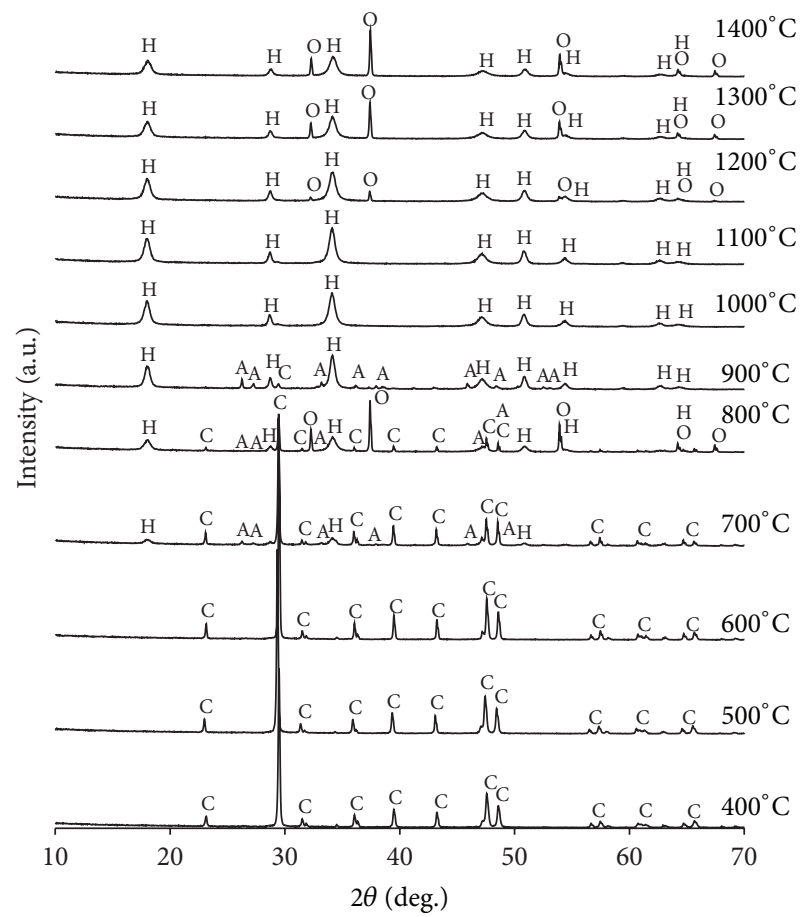

FIGURE 4: PXRD patterns of ACS after calcination at $400-1400^{\circ} \mathrm{C}$ for 3 hours and cooling down with $-10^{\circ} \mathrm{C} \mathrm{min}^{-1}$, which were kept under ambient condition for three months $(\mathrm{C}=$ calcite; $\mathrm{A}=$ aragonite; $\mathrm{H}=$ P-trigonal $\mathrm{Ca}(\mathrm{OH})_{2}$; and $\left.\mathrm{O}=\mathrm{fcc} \mathrm{CaO}\right)$.

crystals found in the ex situ PXRD patterns are listed in Table 1. Biogenic calcite phase remains in the patterns of $400-$ $800^{\circ} \mathrm{C}$. The calcite peaks in the PXRD pattern of $600^{\circ} \mathrm{C}$ were matched with ICSD 073446 of calcite. No peak attributed to impure crystal was found. Sharp peaks of calcite are positioned at $2 \theta$ (Miller indices) $=23.14^{\circ}\left(\begin{array}{lll}0 & 1 & 2\end{array}\right), 29.49^{\circ}(10$

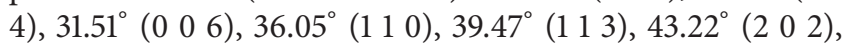
$47.15^{\circ}(024), 47.56^{\circ}(018), 48.57^{\circ}(116), 56.65^{\circ}(211), 57.45^{\circ}$ (1 2 2), 58.16 (1 010 ), 60.74 (2 14$), 61.48^{\circ}$ (1 19 ) , 62.98 (1 2


the PXRD pattern shown in Nave et al. (2004) [28].

The ex situ PXRD patterns of $700-900^{\circ} \mathrm{C}$ showed peaks attributed to calcite, P-orthorhombic $\mathrm{CaCO}_{3}$ (aragonite), and P-trigonal $\mathrm{Ca}(\mathrm{OH})_{2}$ (portlandite). Peaks attributed to portlandite are positioned at $2 \theta=17.96^{\circ}\left(\begin{array}{lll}0 & 0 & 1\end{array}\right), 28.72^{\circ}$ $\left(\begin{array}{lll}1 & 0 & 0\end{array}\right), 34.08^{\circ}\left(\begin{array}{lll}1 & 0 & 1\end{array}\right), 47.13^{\circ}\left(\begin{array}{lll}1 & 0 & 2\end{array}\right)$, and $50.83^{\circ}\left(\begin{array}{lll}1 & 1 & 0\end{array}\right)$. $\mathrm{Ca}(\mathrm{OH})_{2}$ was formed by spontaneous reaction of pyrogenic $\mathrm{CaO}$ slaked with moisture content in atmospheric air during long period of cooling process and air exposure [25]. The nucleation and growing of portlandite crystal started to occur since the pyrogenic $\mathrm{CaO}$ has been cooled down slowly from dehydration temperature of $\mathrm{Ca}(\mathrm{OH})_{2}\left(\sim 600^{\circ} \mathrm{C}\right)$ to room temperature. Therefore, portlandite was not found in the in situ PXRD pattern of ACS heating at instantaneous temperatures $\left(\geq 700^{\circ} \mathrm{C}\right.$ ) under ambient condition (Figure 2). $\mathrm{Ca}(\mathrm{OH})_{2}$ can be dehydrated to form $\mathrm{CaO}$ by reheating it at $350-600^{\circ} \mathrm{C}$ under anhydrous condition $[29,30]$. Besides $\mathrm{P}$ portlandite, PXRD patterns at $700-900^{\circ} \mathrm{C}$ also showed the presence of aragonite. Aragonite was traceable at $2 \theta$ (Miller indices) $=$ $26.28^{\circ}$ (1 111 ), $27.26^{\circ}$ (0 2 1), $33.15^{\circ}$ (0 12 2), $37.92^{\circ}$ (1 112$), 45.91^{\circ}$ (2 2 1), and $48.52^{\circ}\left(\begin{array}{lll}2 & 0 & 2\end{array}\right)$. These peaks were well matched with ICSD 032100 of aragonite. Since aragonite is thermodynamically unstable compared to calcite, transformation of calcite to aragonite at high temperature under ambient condition is impossible [31,32]. Several paths were taken by ACS to form atmospheric aragonite. First, biogenic calcite was decarbonized to form pyrogenic $\mathrm{fcc} \mathrm{CaO}$ at $700-900^{\circ} \mathrm{C}$ as shown in Figure 3. During the slow cooling process, some of $\mathrm{CaO}$ slaked with water from air to form P-trigonal $\mathrm{Ca}(\mathrm{OH})_{2}$. Both $\mathrm{CaO}$ and $\mathrm{Ca}(\mathrm{OH})_{2}$ also experienced recarbonation to form atmospheric $\mathrm{CaCO}_{3}$ in order to reestablish dynamic equilibrium with $\mathrm{CO}_{2}$ at room temperature under ambient condition [33]. Finally, $\mathrm{CaCO}_{3}$ particles were realigned to form aragonite. The peaks intensity attributed to fcc $\mathrm{CaO}$ in the PXRD patterns of $700-900^{\circ} \mathrm{C}$ in Figure 3 diminished compared to the PXRD patterns at the same temperatures in Figure 4, revealing that $\mathrm{fcc} \mathrm{CaO}$ was transformed to both $\mathrm{Ca}(\mathrm{OH})_{2}$ and $\mathrm{CaCO}_{3}$.

The recarbonation process of $\mathrm{fcc} \mathrm{CaO}$ to $\mathrm{CaCO}_{3}$ in air may involve two steps of phase transformation ( $\mathrm{fcc} \mathrm{CaO}$ to aragonite and aragonite to calcite). According to Ostwald's Step Rule, nonordered $\mathrm{CaCO}_{3}$ particles could transform into unstable transient state such as vaterite and aragonite before transforming to the most thermodynamically stable state of calcite $[3,34,35]$. The atmospheric aragonite may be nucleated due to slow cooling process of ACS from calcitearagonite transition temperature to room temperature and then further growing under ambient condition. The calcite peaks in PXRD patterns of $700-800^{\circ} \mathrm{C}$ (Figure 4) may be attributed to the diffraction of both biogenic and atmospheric 
calcite. The formation of atmospheric calcite was significantly traced in PXRD pattern of $900^{\circ} \mathrm{C}$ (Figure 4), where few major peaks of calcite appearing at $29.44^{\circ}, 36.16^{\circ}, 39.50^{\circ}, 42.16^{\circ}$, and $48.42^{\circ}$ are not found in the PXRD pattern in Figure 3.

The presence of portlandite was shown in the PXRD patterns of the temperature around $1000-1400^{\circ} \mathrm{C}$ (Figure 4). It revealed that $\mathrm{fcc} \mathrm{CaO}$ is very hydroscopic to adsorb water molecules from atmospheric air to form portlandite in three months. As a result, fcc $\mathrm{CaO}$ was not significantly traced in the PXRD patterns of $700-1100^{\circ} \mathrm{C}$. Portlandite has the highest diffraction intensity in the pattern of $1100^{\circ} \mathrm{C}$. Its peaks are positioned at $2 \theta$ (Miller indices) $=17.96^{\circ}\left(\begin{array}{lll}0 & 0 & 1\end{array}\right), 28.64^{\circ}\left(\begin{array}{lll}1 & 0 & 0\end{array}\right)$, $34.09^{\circ}(011), 47.11^{\circ}(012), 50.86^{\circ}$ (110), $54.35^{\circ}$ (111), 59.40 $(2$ $00), 62.56^{\circ}$ (2 01$)$, and $64.28^{\circ}$ (112). They matched with ICSD 202231 and the PXRD pattern shown in Ruiz et al. (2009) [25]. The PXRD patterns of $1000-1400^{\circ} \mathrm{C}$ do not show any peak attributed to atmospheric calcite and atmospheric aragonite. It revealed that high temperature of calcination process may improve the crystallinity of pyrogenic fcc $\mathrm{CaO}$ and can retain its structure from complete hydration by atmospheric air in three months. The hydrated form of pyrogenic fcc $\mathrm{CaO}$ which crystallized to portlandite crystal has higher chemical resistivity against recarbonation by atmospheric air. The highest peaks intensity of $\mathrm{fcc} \mathrm{CaO}$ was found in the PXRD pattern of $1400^{\circ} \mathrm{C}$. They are positioned at $2 \theta$ (Miller indices) $=32.30^{\circ}(111), 37.44^{\circ}(111), 53.92^{\circ}$ (2 20$), 64.21^{\circ}$ (3 1 1), and $67.44^{\circ}$ (2 2 2). The result was well matched with ICSD 75785 and the PXRD pattern shown in Nave et al. (2004) [28].

Figure 5 showed FTIR spectra of ACS after calcination at $400-1400^{\circ} \mathrm{C}$ which were kept at room temperature under ambient condition for three months. ACS which has been calcined at $400^{\circ} \mathrm{C}$ has three strong IR absorption bands at 1399,870 , and $711 \mathrm{~cm}^{-1}$. These bands indicated the presence of $\mathrm{CO}_{3}{ }^{2}$ attached to calcium ion $\left(\mathrm{Ca}^{2+}\right)$ in calcite structure $[2,5,22,25]$. These bands also correspond to the modes of asymmetric stretch $\left(v_{4}\right)$, out-plane bend $\left(v_{2}\right)$, and in-plane bend $\left(v_{3}\right)$ vibrations of $\mathrm{C}-\mathrm{O}$ bonds in calcite $[21,23,24,36]$. A weak IR absorption band at $1793 \mathrm{~cm}^{-1}$ corresponded to $\mathrm{C}=\mathrm{O}$ bond in calcite [25]. Besides, three weak IR absorption bands were found in the spectrum at 3743 and $2512 \mathrm{~cm}^{-1}$. They were attributed to bond vibration of $\mathrm{H}-\mathrm{OH}$ of water and $\mathrm{Ca}-\mathrm{OH}_{2}$ of calcite. We deduced that $\mathrm{H}_{2} \mathrm{O}$ from atmospheric air was adsorbed by $\mathrm{CaCO}_{3}$ via chemisorption and physisorption. Chemisorption of $\mathrm{H}_{2} \mathrm{O}$ may form tiny hydrated $\mathrm{CaCO}_{3}$ crystal which is below the detectable range of PXRD. Monohydrocalcite crystal is more likely to be presented in ACS compared to amorphous $\mathrm{CaCO}_{3}$ and ikaite because monohydrocalcite is more kinetically stable at room temperature and pressure $[13,37,38]$. The chemical equation which represents the hydroadsorption of calcite was shown in (1). The FTIR spectra of ACS after calcination from 400 to $600^{\circ} \mathrm{C}$ do not show any significant changes in chemical bonds:

$$
\mathrm{CaCO}_{3}(\mathrm{~s} \text {, biogenic calcite })+x \mathrm{H}_{2} \mathrm{O}(\mathrm{g}) \longrightarrow \mathrm{CaCO}_{3} \cdot x \mathrm{H}_{2} \mathrm{O}(\mathrm{s} \text {, monohydrocalcite) }
$$

FTIR spectrum changed as ACS was being calcined at $700^{\circ} \mathrm{C}$. Two new IR absorption bands appeared at 3640 and $502 \mathrm{~cm}^{-1}$ in the FTIR spectrum of $700^{\circ} \mathrm{C}$. They were contributed by vibration of $\mathrm{Ca}-\mathrm{OH}$ bond in $\mathrm{Ca}(\mathrm{OH})_{2}$ and $\mathrm{Ca}-\mathrm{O}$ bond in $\mathrm{CaO}$ [36]. The strong and sharp band at $1408 \mathrm{~cm}^{-1}$ was resultant IR absorptions by asymmetric C-O bond vibration in calcite/aragonite and $\mathrm{Ca}-\mathrm{O}$ bond vibration in $\mathrm{CaO}$ [25]. The spectrum revealed that biogenic $\mathrm{CaCO}_{3}$ was partially decomposed to form pyrogenic $\mathrm{CaO}$ during calcination (see (2)) and then hydrated to form atmospheric $\mathrm{Ca}(\mathrm{OH})_{2}$ under ambient condition (see $(3)$ ) $[25,39]$. The result was consistent with the PXRD result of $700^{\circ} \mathrm{C}$ in Figure 4. The IR absorption bands of $\mathrm{CaCO}_{3}$ in the spectrum may have resulted by the overlapping of IR absorption of biogenic calcite as well as recarbonized atmospheric calcite and aragonite (see (4)):

$$
\begin{aligned}
& \mathrm{CaCO}_{3}(\text { s, biogenic calcite }) \longrightarrow \mathrm{CaO}(\mathrm{s} \text {, pyrogenic fcc })+\mathrm{CO}_{2}(\mathrm{~g}) \\
& \left.\mathrm{CaO}(\text { s, pyrogenic fcc })+\mathrm{H}_{2} \mathrm{O}(\mathrm{g}) \longrightarrow \mathrm{Ca}(\mathrm{OH})_{2} \text { (s, atmospheric portlandite }\right) \\
& \mathrm{CaO}(\text { s, pyrogenic fcc })+\mathrm{CO}_{2}(\mathrm{~g}) \longrightarrow \mathrm{CaCO}_{3}\left(\mathrm{~s}, \frac{\text { atmospheric aragonite }}{\text { calcite }}\right)
\end{aligned}
$$

$\mathrm{Ca}^{2+}$ has high magnitude of charge and small ionic radius. Therefore, it has high charge density and polarization strength. $\mathrm{CO}_{3}{ }^{2-}$ in calcite has larger ionic size compared to $\mathrm{O}^{2-}$ in $\mathrm{CaO}$. The large electron cloud of $\mathrm{CO}_{3}{ }^{2-}$ can be polarized by $\mathrm{Ca}^{2+}$ and ascended higher covalent character of $\mathrm{CaO}-\mathrm{CO}_{2}$ bond in calcite. At high temperature, $\mathrm{Ca}^{2+}$ pulls electron pair of $\mathrm{Ca}-\mathrm{OCO}_{2}$ closer towards itself and strengthens the bond. Large ionic size of $\mathrm{CO}_{3}{ }^{2-}$ caused the $\mathrm{CaO}-\mathrm{CO}_{2}$ bond to experience larger magnitude of bond strain of vibration. It weakens the $\mathrm{CaO}-\mathrm{CO}_{2}$ bond strength at high temperature. With calcination $\geq 700^{\circ} \mathrm{C}$, calcite gained enough energy to break the $\mathrm{CaO}-\mathrm{CO}_{2}$ bond and form $\mathrm{CaO}$ and $\mathrm{CO}_{2}$ gas as shown in (2). $\mathrm{Ca}-\mathrm{O}$ bond in $\mathrm{CaO}$ has higher ionic character and higher bond strength than $\mathrm{Ca}-\mathrm{OCO}_{2}$ in 


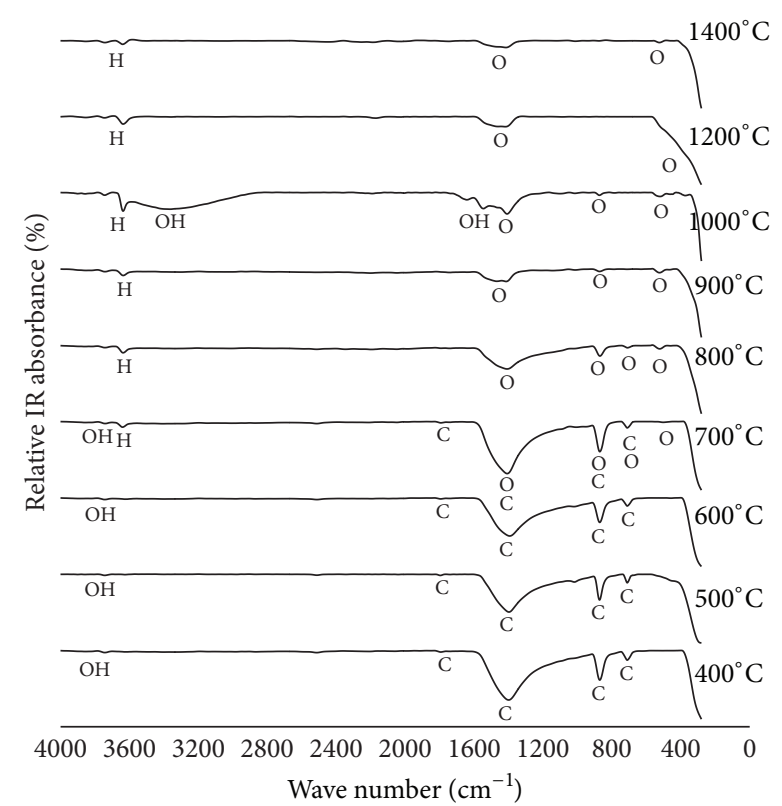

FIGURE 5: IR absorption spectra of ACS after calcination at 400$1400^{\circ} \mathrm{C}$ for 3 hours and cooling down with $-10^{\circ} \mathrm{C} \mathrm{min}^{-1}$, which were kept under ambient condition for three months $(\mathrm{C}=$ bonds of calcite; $\mathrm{OH}=\mathrm{O}-\mathrm{H}$ and $\mathrm{Ca}-\mathrm{OH}_{2}$ bonds of water; $\mathrm{H}=\mathrm{Ca}-\mathrm{OH}$ in $\mathrm{Ca}(\mathrm{OH})_{2}$; and $\mathrm{O}=\mathrm{Ca}-\mathrm{O}$ bond in $\mathrm{CaO}$ ).

calcite. Therefore, $\mathrm{CaO}$ has higher thermodynamic stability than calcite at high temperature.

$\mathrm{CaO}$ has higher hydroadsorption strength than calcite because it is more polar than calcite. Both $\mathrm{Ca}^{2+}$ and $\mathrm{O}^{2-}$ sites in $\mathrm{CaO}$ can undergo physisorption with $\mathrm{H}_{2} \mathrm{O}$ to form $\mathrm{Ca}-\mathrm{OH}_{2}$ bond. Besides, large ionic size of $\mathrm{CO}_{3}{ }^{2-}$ in $\mathrm{CaCO}_{3}$ reduced free site of $\mathrm{Ca}$ to adsorb $\mathrm{H}_{2} \mathrm{O}$. $\mathrm{CaO}$ also has high chemisorption strength with $\mathrm{H}_{2} \mathrm{O}$ to form $\mathrm{Ca}(\mathrm{OH})_{2}$ with $\mathrm{Ca}-\mathrm{OH}$ bonds. $\mathrm{Ca}(\mathrm{OH})_{2}$ is more kinetically stable than $\mathrm{CaO}$ because $\mathrm{CaO}$ has low activation energy to react with $\mathrm{H}_{2} \mathrm{O}$ exothermically to form $\mathrm{Ca}(\mathrm{OH})_{2}$ (see (3)). As a result, $\mathrm{Ca}(\mathrm{OH})_{2}$ was traced in the FTIR spectrum of $700^{\circ} \mathrm{C}$ as $\mathrm{CaO}$ formed by decomposition of $\mathrm{CaCO}_{3}$.

The IR absorption bands of calcite/aragonite decreased in the spectrum of $800^{\circ} \mathrm{C}$ and disappeared in the spectrum of $900^{\circ} \mathrm{C}$. Four IR absorption bands in the FTIR spectra of $800^{\circ} \mathrm{C}$ positioned at $2190,1415,875$, and $520 \mathrm{~cm}^{-1}$ were attributed to the presence of $\mathrm{CaO}$ [25]. The IR absorption bands of $\mathrm{CaO}$ increased from 700 to $1000^{\circ} \mathrm{C}$. It revealed that the content of $\mathrm{CaO}$ increased. Since $\mathrm{CaO}$ has a hygroscopic property, the formation of $\mathrm{Ca}(\mathrm{OH})_{2}$ increased parallel with the increases of $\mathrm{CaO}$ particles. It was supported by FTIR spectra which showed that IR absorption bands of $\mathrm{Ca}(\mathrm{OH})_{2}$ increased from 700 to $1000^{\circ} \mathrm{C}$. The highest hydroadsorption strength of ACS was achieved as it was cooled down from $1000^{\circ} \mathrm{C}$. A new broad band at $3640-2800 \mathrm{~cm}^{-1}$ appeared in the FTIR spectrum of $1000^{\circ} \mathrm{C}$. It represented the presence of $\mathrm{Ca}-\mathrm{OH}_{2}$ and $\mathrm{H}-\mathrm{OH}$ bonds due to physisorption of water by $\mathrm{CaO}$.

The FTIR spectra of 1200 and $1400^{\circ} \mathrm{C}$ showed that the IR absorption bands of $\mathrm{CaO}$ decreased. It was due to the fact

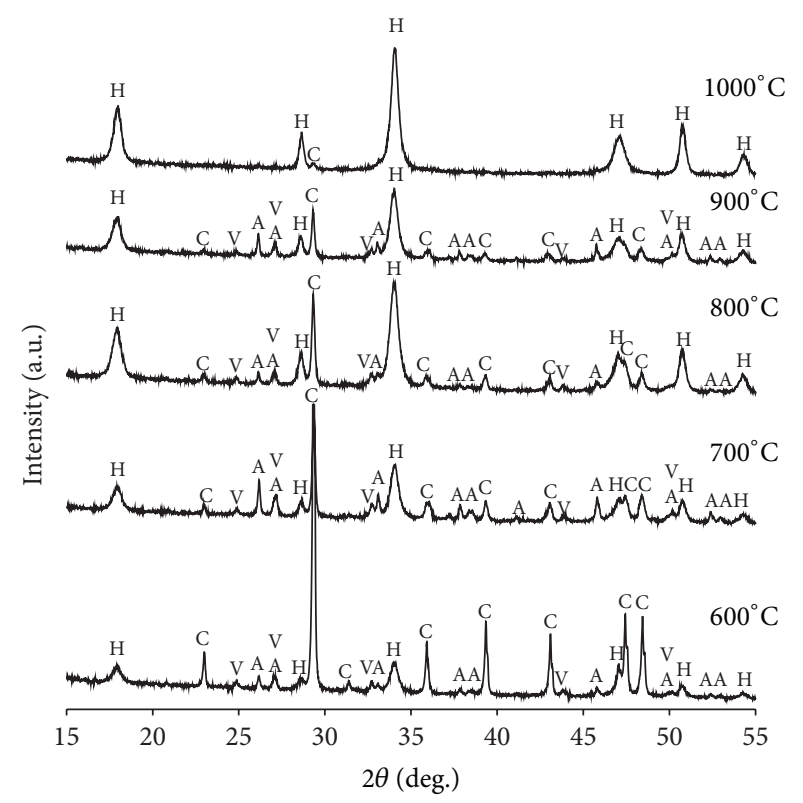

FIGURE 6: PXRD patterns of ACS after calcination at $600-1000^{\circ} \mathrm{C}$ for

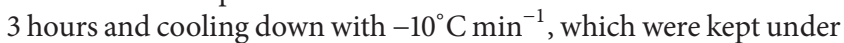
ambient condition for nine months $(\mathrm{C}=$ calcite; $\mathrm{A}=$ aragonite; $\mathrm{H}=$ P-trigonal $\mathrm{Ca}(\mathrm{OH})_{2}$; and $\left.\mathrm{O}=\mathrm{fcc} \mathrm{CaO}\right)$.

that further crystallization of fcc $\mathrm{CaO}$ at higher temperature limited the magnitude of $\mathrm{Ca}-\mathrm{O}$ bond vibrations. However, the intensity of IR band attributed to hydroxide ions $\left(\mathrm{OH}^{-}\right)$at $\sim 3640 \mathrm{~cm}^{-1}$ does not change significantly. It revealed that the high crystallinity of fcc $\mathrm{CaO}$ at high temperature limited the nucleation and growth of $\mathrm{Ca}(\mathrm{OH})_{2}$ crystal (Figure 3). No IR absorption band attributed to calcite and aragonite was found in the spectra. Hence, we deduced that high crystallinity of fcc $\mathrm{CaO}$ can slow down the recarbonation rate of $\mathrm{CaO}$.

In order to further investigate the time-dependent recarbonation and hydration of calcined ACS at $600-1000^{\circ} \mathrm{C}$ exposed to atmospheric air, PXRD tests were carried out after nine months of calcination and the result was shown in Figure 6. The results revealed that ACS samples underwent decarbonation, hydration, and recarbonation. The PXRD pattern of $600^{\circ} \mathrm{C}$ was matched with the diffraction patterns of calcite, aragonite, vaterite, and portlandite. The major phase was calcite. The result showed that the original biogenic calcite was decarbonized and hydrated by atmospheric air to form portlandite. Conversion of stable calcite phase to less stable aragonite and vaterite polymorphs under ambient temperature and pressure is not thermodynamically favourable crystallographic transformation. The crystallization of aragonite and vaterite reflects the fact that the original biogenic calcite in ACS was decarbonized and recarbonized by atmospheric air. The recarbonized $\mathrm{CaCO}_{3}$ might form the least stable of amorphous $\mathrm{CaCO}_{3}$ polymorphs first before recrystallization. The amorphous $\mathrm{CaCO}_{3}$ underwent nucleation of vaterite first followed by transformation towards more stable aragonite and then the most stable calcite [35]. The presence of aragonite was observed at $2 \theta=26.16^{\circ}, 27.10^{\circ}$, $33.12^{\circ}, 35.92^{\circ}, 37.85^{\circ}, 38.45^{\circ}, 45.80^{\circ}, 50.04^{\circ}, 52.39^{\circ}$, and $52.95^{\circ}$, 
whereas vaterite was observed at $2 \theta=24.96^{\circ}, 27.10^{\circ}, 32.71^{\circ}$, $43.81^{\circ}, 48.58^{\circ}$, and $50.04^{\circ}$. Hence, the diffraction of calcite observed in the pattern resulted by both biogenic calcite and atmospheric calcite. The crystallization of portlandite reflects the fact that the original biogenic calcite in ACS was decarbonized to $\mathrm{CaO}$, hydrated to $\mathrm{Ca}(\mathrm{OH})_{2}$, and then crystallized to form portlandite by atmospheric air. The presence of portlandite was observed at $2 \theta=17.93^{\circ}, 28.56^{\circ}$, $34.02^{\circ}, 47.06^{\circ}, 50.68^{\circ}$, and $54.25^{\circ}$.

The PXRD patterns of $700-900^{\circ} \mathrm{C}$ in Figure 6 also showed the presence of calcite, aragonite, vaterite, and portlandite. However, the patterns have lower diffraction intensity of calcite compared to the pattern of $600^{\circ} \mathrm{C}$. It reflects the fact that the biogenic calcite in ACS was decarbonized to fcc $\mathrm{CaO}$ during calcination but does not fully recover by atmospheric recarbonation. The patterns do not show the presence of fcc $\mathrm{CaO}$. It revealed that $\mathrm{fcc} \mathrm{CaO}$ that crystallized during calcination is not stable when exposed to atmospheric air. In addition, $\mathrm{CaO}$ which decarbonized by atmospheric air does not crystallize to fcc $\mathrm{CaO}$. The high hygroscopic behaviour of $\mathrm{CaO}$ made $\mathrm{CaO}$ adsorb water rapidly from atmospheric air to form portlandite and made it unable to retain its fcc $\mathrm{CaO}$ structure for long period. Besides, the pyrogenic fcc $\mathrm{CaO}$ also underwent recarbonation to form calcite, aragonite, and vaterite phases as shown in the patterns of $700-900^{\circ} \mathrm{C}$. The sequence of hydration and recarbonation of $\mathrm{CaO}$ by atmospheric $\mathrm{H}_{2} \mathrm{O}$ and $\mathrm{CO}_{2}$ is expressed as follows:

$$
\mathrm{CaO}+\mathrm{CO}_{2}+\mathrm{H}_{2} \mathrm{O} \longleftrightarrow \mathrm{Ca}(\mathrm{OH})_{2}+\mathrm{CO}_{2} \longleftrightarrow \mathrm{CaCO}_{3}+\mathrm{H}_{2} \mathrm{O}
$$

The PXRD pattern of $1000^{\circ} \mathrm{C}$ in Figure 6 only consists of diffraction pattern of portlandite and a main calcite peak at $29.32^{\circ}$. The result revealed that high crystallinity of pyrogenic fcc $\mathrm{CaO}$ which was exposed to atmospheric air formed a stable atmospheric portlandite phase. The portlandite phase has a high resistivity to inhibit recarbonation. Hence, small amount of atmospheric calcite was nucleated. No intermediate phase transition of $\mathrm{CaCO}_{3}$ (aragonite and vaterite) was observed.

\section{Conclusion}

A series of calcinations at variation temperature (400$1400^{\circ} \mathrm{C}$ ) was carried out on disposed ACS which originates from Straits of Malacca. In situ PXRD analysis was conducted on ACS powder at instantaneous temperatures under ambient condition, whereas ex situ PXRD analysis was conducted on ACS powder after calcination and cooling down $\left(-10^{\circ} \mathrm{C} \mathrm{min}^{-1}\right)$ to room temperature. In general, both in situ and ex situ PXRD analyses showed that the biogenic calcite in ACS is decarbonized to form pyrogenic fcc $\mathrm{CaO}$ at $650-800^{\circ} \mathrm{C}$ under ambient condition. The crystallinity of pyrogenic fcc $\mathrm{CaO}$ increases as calcination temperature increases. In situ PXRD result showed that the biogenic calcite grew at 600$650^{\circ} \mathrm{C}$ and is completely decarbonized at $800^{\circ} \mathrm{C}$. The pyrogenic fcc $\mathrm{CaO}$ was nucleated at $650^{\circ} \mathrm{C}$ and further crystallized at higher temperature. However, ACS after decarbonation at $\geq 700^{\circ} \mathrm{C}$ and cooling down to room temperature under ambient condition induced reestablishment of new dynamic equilibrium via $\mathrm{H}_{2} \mathrm{O}$ and $\mathrm{CO}_{2}$ adsorption of pyrogenic $\mathrm{CaO}$. Evidence of reestablishment of new dynamic equilibrium was observed from the PXRD analysis of decarbonized ACS after three months of atmospheric air exposure. Hydration of pyrogenic fcc $\mathrm{CaO}$ in atmospheric air induced crystallization of atmospheric portlandite in ACS after calcination at 700$1400^{\circ} \mathrm{C}$. Recarbonation of pyrogenic fcc $\mathrm{CaO}$ in atmospheric air caused crystallization of atmospheric calcite as well as intermediate phase of aragonite and vaterite in the ACS after calcination at $700-900^{\circ} \mathrm{C}$. The result agrees with Ostwald's Step Rule, where recarbonation of fcc $\mathrm{CaO}$ crystallizes the least stable polymorph of $\mathrm{CaCO}_{3}$ first before transforming to stable calcite. The PXRD result also revealed that high crystallinity of pyrogenic fcc $\mathrm{CaO}$ has higher resistivity to recarbonation. fcc $\mathrm{CaO}$ is not a stable phase in atmospheric air. FTIR analysis on the ACS after calcination and three months of atmospheric air exposure under ambient condition reflects the hygroscopic effect on both calcite and $\mathrm{CaO}$. Calcite slightly adsorbed $\mathrm{H}_{2} \mathrm{O}$ to form monohydrocalcite in short range order. $\mathrm{CaO}$ is very hygroscopic. It adsorbed $\mathrm{H}_{2} \mathrm{O}$ spontaneously to form $\mathrm{Ca}(\mathrm{OH})_{2}$. ACS has highest degree of $\mathrm{H}_{2} \mathrm{O}$ adsorption as ACS after decarbonation at $1000^{\circ} \mathrm{C}$. FTIR spectrum also revealed that calcite decomposed at $600-$ $800^{\circ} \mathrm{C}$. $\mathrm{CaO}$ and $\mathrm{Ca}(\mathrm{OH})_{2}$ coexisted in the ACS after cooling down from $700-1400^{\circ} \mathrm{C}$ to room temperature. Overall, PXRD analysis is more appropriate to study polymorphic transformation in recarbonation of pyrogenic $\mathrm{CaO}$, whereas FTIR analysis is more appropriate to study hydration of biogenic calcite and pyrogenic $\mathrm{CaO}$.

\section{Conflict of Interests}

The authors declare that there is no conflict of interests regarding the publication of this paper.

\section{Acknowledgment}

The authors gratefully acknowledge the financial support from the Malaysian Ministry of Higher Education (MOHE) through Research University Grant Scheme (RUGS).

\section{References}

[1] J. Chen and L. Xiang, "Controllable synthesis of calcium carbonate polymorphs at different temperatures," Powder Technology, vol. 189, no. 1, pp. 64-69, 2009.

[2] F. B. Reig, J. V. G. Adelantado, and M. C. M. Moya Moreno, "FTIR quantitative analysis of calcium carbonate (calcite) and silica (quartz) mixtures using the constant ratio method. Application to geological samples," Talanta, vol. 58, no. 4, pp. 811-821, 2002.

[3] W. Sun, S. Jayaraman, W. Chen, K. A. Persson, and G. Ceder, "Nucleation of metastable aragonite $\mathrm{CaCO}_{3}$ in seawater," Proceedings of the National Academy of Sciences of the United States of America, vol. 112, no. 11, pp. 3199-3204, 2015.

[4] H. Nebel and M. Epple, "Continuous preparation of calcite, aragonite and vaterite, and of magnesium-substituted amorphous calcium carbonate (Mg-ACC)," Zeitschrift fur Anorganische und Allgemeine Chemie, vol. 634, no. 8, pp. 1439-1443, 2008. 
[5] S. W. Lee, Y. M. Kim, R. H. Kim, and C. S. Choi, "Nanostructured biogenic calcite: a thermal and chemical approach to folia in oyster shell," Micron, vol. 39, no. 4, pp. 380-386, 2008.

[6] Y. S. Ok, S.-E. Oh, M. Ahmad et al., "Effects of natural and calcined oyster shells on $\mathrm{Cd}$ and $\mathrm{Pb}$ immobilization in contaminated soils," Environmental Earth Sciences, vol. 61, no. 6, pp. 1301-1308, 2010.

[7] F. Wheaton, "Review of oyster shell properties: part II. Thermal properties," Aquacultural Engineering, vol. 37, no. 1, pp. 14-23, 2007.

[8] B. Pokroy, J. P. Quintana, E. N. Caspi, A. Berner, and E. Zolotoyabko, "Anisotropic lattice distortions in biogenic aragonite," Nature Materials, vol. 3, no. 12, pp. 900-902, 2004.

[9] B. Pokroy, A. N. Fitch, and E. Zolotoyabko, "Structure of biogenic aragonite (CaCO3)," Crystal Growth \& Design, vol. 7, no. 9, pp. 1580-1583, 2007.

[10] J. Wang, Y. Xu, Y. Zhao et al., "Morphology and crystalline characterization of abalone shell and mimetic mineralization," Journal of Crystal Growth, vol. 252, no. 1-3, pp. 367-371, 2003.

[11] G. Simmons and P. Bell, "Calcite-aragonite equilibrium," Science, vol. 139, no. 3560, pp. 1197-1198, 1963.

[12] L. Brečević and D. Kralj, "On calcium carbonates: from fundamental research to application," Croatica Chemica Acta, vol. 80, no. 3-4, pp. 467-484, 2007.

[13] B. Dickens and W. E. Brown, "The crystal structure of calcium carbonate hexahydrate at $\sim-120^{\circ}$," Inorganic Chemistry, vol. 9, no. 3, pp. 480-486, 1970.

[14] H. Nebel, M. Neumann, C. Mayer, and M. Epple, "On the structure of amorphous calcium carbonate-a detailed study by solid-state NMR spectroscopy," Inorganic Chemistry, vol. 47, no. 17, pp. 7874-7879, 2008.

[15] M. M. Tlili, M. B. Amor, C. Gabrielli, S. Joiret, G. Maurin, and P. Rousseau, "Characterization of $\mathrm{CACO}_{3}$ hydrates by microRaman spectroscopy," Journal of Raman Spectroscopy, vol. 33, no. 1, pp. 10-16, 2002.

[16] M. J. Broom, "Gonad development and spawning in Anadara granosa (L.) (Bivalvia: Arcidae)," Aquaculture, vol. 30, no. 1-4, pp. 211-219, 1983.

[17] C. W. Loy, Effects of heat treatment on structure and thermal diffusivites of $\mathrm{SiO}_{2}-\mathrm{Al}_{2} \mathrm{O}_{3}-\mathrm{Na}_{2} \mathrm{O}-\mathrm{CaO}-\mathrm{CaF}_{2}$ glass-ceramics from waste materials [M.S. thesis], Universiti Putra Malaysia, 2012.

[18] J. D. Bronzino, "Tissue engineering and artificial organs," in The Biomedical Engineering Handbook, pp. 24-26, CRC Press, Boca Raton, Fla, USA, 3rd edition, 2006.

[19] S. Goffredo, P. Vergni, M. Reggi et al., "The skeletal organic matrix from Mediterranean coral Balanophyllia europaea influences calcium carbonate precipitation," PLOS ONE, vol. 6, no. 7, Article ID e22338, 7 pages, 2011.

[20] J. Mahamid, A. Sharir, L. Addadi, and S. Weiner, "Amorphous calcium phosphate is a major component of the forming fin bones of zebrafish: indications for an amorphous precursor phase," Proceedings of the National Academy of Sciences of the United States of America, vol. 105, no. 35, pp. 12748-12753, 2008.

[21] K. Nakamoto, Infrared and Raman Spectra of Inorganic and Coordination Compounds, Part A: Theory and Applications in Inorganic Chemistry, Wesley, New York, NY, USA, 6th edition, 1970.

[22] R. A. Nyquist and R. O. Kagel, Infrared Spectra of Inorganic Compounds, Academic Press, New York, NY, USA, 1971.

[23] V. C. Farmer, The Infrared Spectra of Minerals, Mineralogical Society, London, UK, 1974.
[24] S. Bhagavantam and T. Venkatarayudu, "Raman effect in relation to crystal structure," Proceedings of the Indian Academy of Sciences A, vol. 9, no. 3, pp. 224-258, 1939.

[25] M. G. Ruiz, J. Hernández, L. Baños, J. N. Montes, and M. E. R. García, "Characterization of calcium carbonate, calcium oxide, and calcium hydroxide as starting point to the improvement of lime for their use in construction," Journal of Materials in Civil Engineering, vol. 21, no. 11, pp. 694-698, 2009.

[26] H.-B. Kwon, C.-W. Lee, B.-S. Jun, J.-D. Yun, S.-Y. Weon, and B. Koopman, "Recycling waste oyster shells for eutrophication control," Resources, Conservation and Recycling, vol. 41, no. 1, pp. 75-82, 2004.

[27] N. Huang and J. Wang, "A TGA-FTIR study on the effect of $\mathrm{CaCO}_{3}$ on the thermal degradation of EBA copolymer," Journal of Analytical and Applied Pyrolysis, vol. 84, no. 2, pp. 124-130, 2009.

[28] D. Nave, S. Rosenwaks, R. Vago, and I. Bar, "Pulsed laser deposition of marine origin material: preparation and characterization of $\mathrm{CaCO}_{3}$ particles and $\mathrm{CaO}$ nanocrystals," Journal of Applied Physics, vol. 95, no. 12, pp. 8309-8313, 2004.

[29] J. O. Chae, S. P. Knak, A. N. Knak, H. J. Koo, and V. Ravi, "Oyster shell recycling and bone waste treatment using plasma pyrolysis," Plasma Science and Technology, vol. 8, no. 6, pp. 712$715,2006$.

[30] A. Irabien, J. R. Viguri, and I. Ortiz, "Thermal dehydration of calcium hydroxide. 1. Kinetic model and parameters," Industrial \& Engineering Chemistry Research, vol. 29, no. 8, pp. 1599-1606, 1990.

[31] M. B. Toffolo and E. Boaretto, "Nucleation of aragonite upon carbonation of calcium oxide and calcium hydroxide at ambient temperatures and pressures: a new indicator of fire-related human activities," Journal of Archaeological Science, vol. 49, no. 1, pp. 237-248, 2014.

[32] G. Zhang, Y. Guo, J. Ao, J. Yang, G. Lv, and K. Shih, "Thermally induced phase transformation of pearl powder," Materials Science and Engineering C, vol. 33, no. 4, pp. 2046-2049, 2013.

[33] V. Morales-Flórez, A. Santos, I. Romero-Hermida, and L. Esquivias, "Hydration and carbonation reactions of calcium oxide by weathering: kinetics and changes in the nanostructure," Chemical Engineering Journal, vol. 265, pp. 194-200, 2015.

[34] S.-Y. Chung, Y.-M. Kim, J.-G. Kim, and Y.-J. Kim, "Multiphase transformation and Ostwald's rule of stages during crystallization ofametal phosphate," Nature Physics, vol. 5, no. 1, pp. 68-73, 2009.

[35] W. Ostwald, "Studien uber die bildung und umwandlung fester korper. 1. Abhandlung ubersattgung und uberkaltung," Zeitschrift für Physikalische Chemie, vol. 22, pp. 289-330, 1897.

[36] T. Witoon, "Characterization of calcium oxide derived from waste eggshell and its application as $\mathrm{CO}_{2}$ sorbent," Ceramics International, vol. 37, no. 8, pp. 3291-3298, 2011.

[37] H. Hull and A. G. Turnbull, "A thermochemical study of monohydrocalcite," Geochimica et Cosmochimica Acta, vol. 37, no. 3, pp. 685-694, 1973.

[38] G. Marland, "The stability of $\mathrm{CaCO}_{3} \cdot 6 \mathrm{H}_{2} \mathrm{O}$ (ikaite)," Geochimica et Cosmochimica Acta, vol. 39, no. 1, pp. 83-91, 1975.

[39] G. Vogg, L. J.-P. Meyer, C. Miesner, M. S. Brandt, and M. Stutzmann, "Polygermanosilyne calcium hydroxide intercalation compounds formed by topotactic transformation of $\mathrm{Ca}\left(\mathrm{Si}_{1-x} \mathrm{Ge}_{x}\right)_{2}$ alloy zintl phases in ambient atmosphere," Monatshefte für Chemie, vol. 132, no. 10, pp. 1125-1135, 2001. 

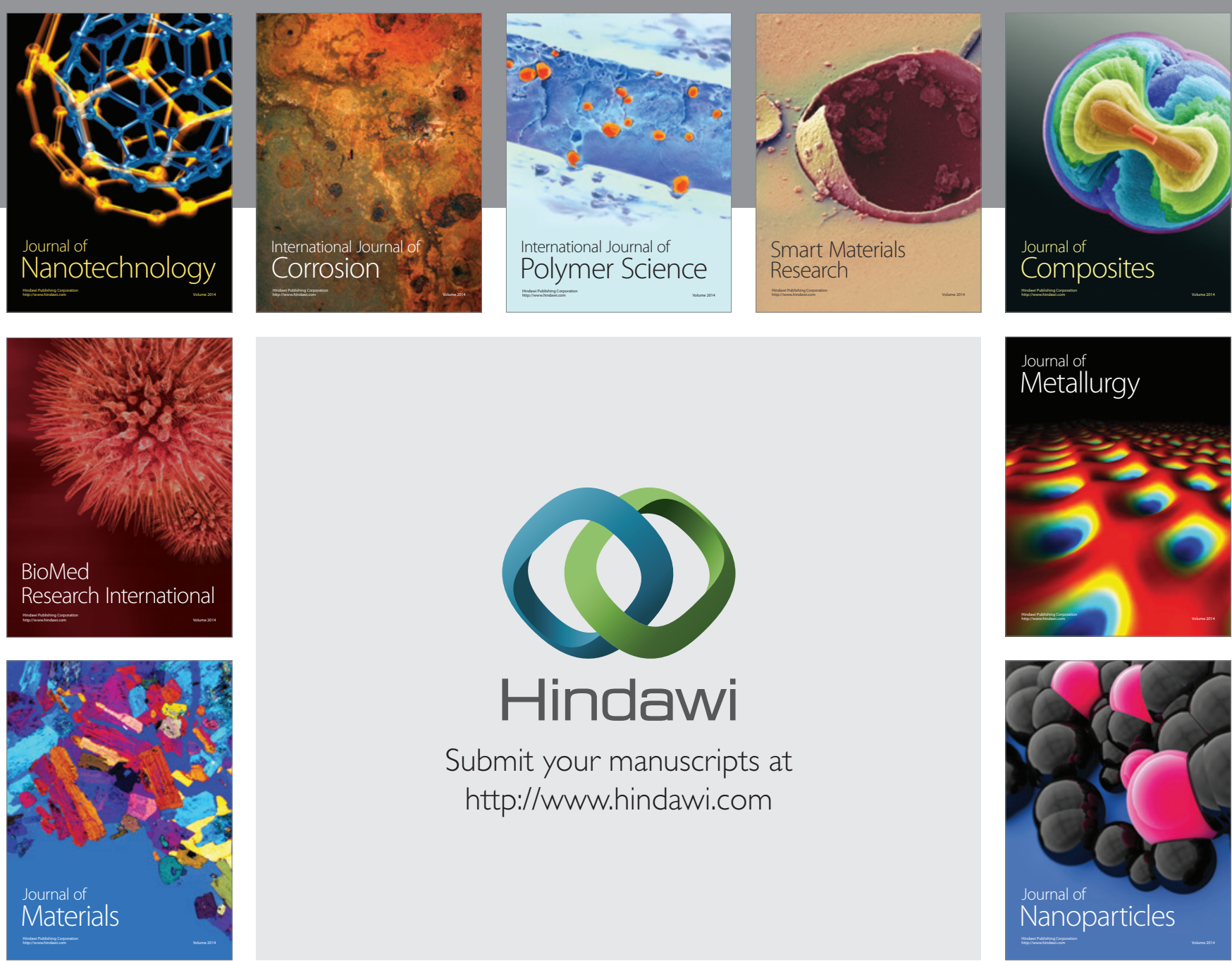

\section{Hindawi}

Submit your manuscripts at

http://www.hindawi.com

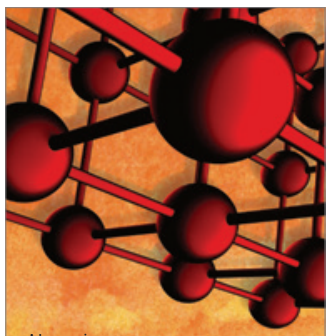

Materials Science and Engineering

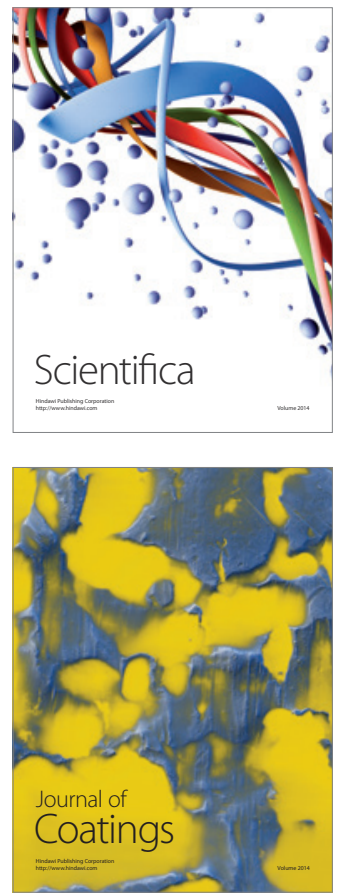
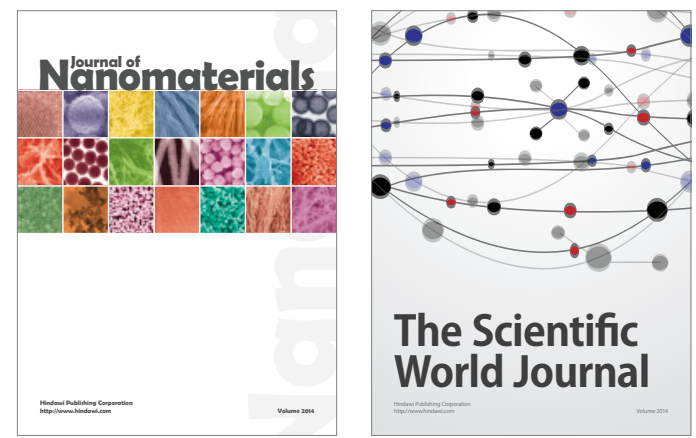

The Scientific World Journal
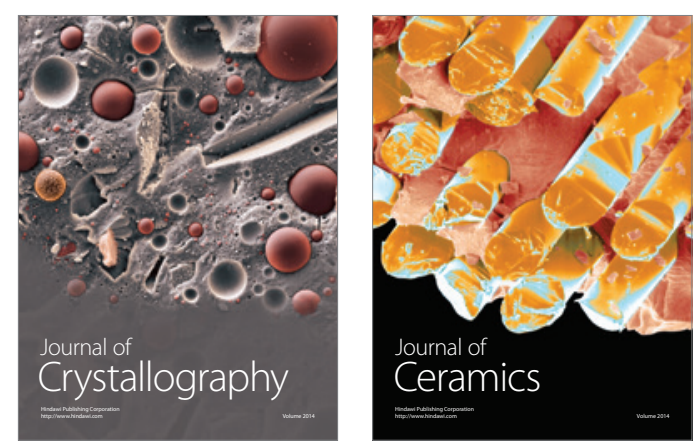
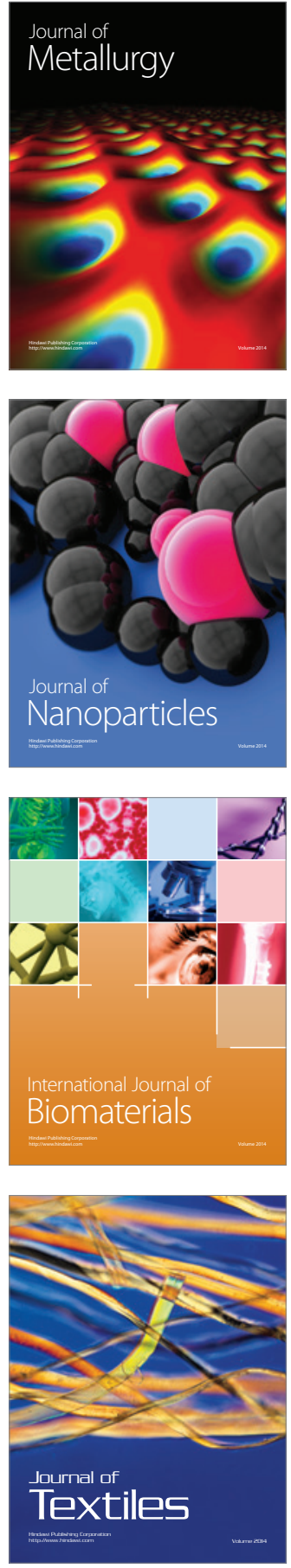